\title{
STUDI KASUS : INTERAKSI SOSIAL ANTAR PEKERJA SEKS KOMERSIAL (PSK) DI BENGKULU
}

\author{
Deltari Novitasari \\ STIKES Bhakti Husada Bengkulu \\ Jl. Kinibalu 8 Kebun Tebeng Bengkulu Telp. (0736) 23422 \\ Email: kinufidan@gmail.com
}

\begin{abstract}
ABSTRAK
Mereka cenderung beroperasi tengah malam dan memiliki kode-kode supaya tidak terjaring petugas keamanan dan PSK cenderung menyembunyikan identitas mereka sebagai PSK supaya tetap diterima masyarakat dan bersosialisasi dengan baik. Komunikasi antar PSK biasanya lebih banyak menggunakan bahasa non verbal, cara ini supaya memudahkan interaksi dan pergaulan dengan sesama PSK. Tujuan penelitian ini untuk mengetahui komunikasi serta interaksi yang terjadi sesama PSK, mengetahui hubungan sosial dari PSK, mengetahui kehidupan sosial sesama PSK. Metode Penelitian menggunakan pendekatan kualitatif dengan instrumen penelitian observasi dan wawancara. Hasil penelitian menyatakan bahwa subjek dalam berinteraksi antar sesama PSK kurang baik dan terjadi persaingan. Subjek merasa pilihannya menjadi seorang PSK sudah tepat untuk memenuhi kebutuhan ekonomi keluarganya. Saran kepada subjek untuk memperhatikan kesehatan reproduksi dan untuk masyarakat untuk membina hubungan baik kepada subjek agar diberi pengarahan tentang bahaya profesi PSK.
\end{abstract}

Kata kunci: Interaksi Sosial, Pekerja Seks Komersial (PSK)

\begin{abstract}
They tend to operate in the middle of the night and have codes so that no security officers are netted and PSK tend to conceal their identities as PSK so that they remain accepted by the community and socialize well. Communication between PSK usually uses non-verbal language, this way in order to facilitate interaction and association with fellow PSK. The purpose of this study is to find out the communication and interactions that occur among PSK, find out the social relationships of PSK, find out the social lives of fellow PSK. The research method uses a qualitative approach with observation and interview research instruments. The results of the study stated that the subjects in interacting with fellow sex workers were not good enough and there was competition. The subject felt his choice to become a PSK was right to meet the economic needs of his family. Suggestions for subjects to pay attention to reproductive health and for the community to foster good relations with the subject so that they are given a briefing about the dangers of the profession of PSK.
\end{abstract}

Key Word : Social Interaction, Prostitute 


\section{PENDAHULUAN}

Pekerja Seks Komersial (PSK) tidak asing lagi terdengar dan terkesan negatif. Alasan utama ketika seseorang menjadi PSK yaitu kesulitan ekonomi, gaya hidup dan pergaulan. Kategori usia PSK di mulai dari remaja sampai wanita dewasa, dengan status pelajar, ibu rumah tangga yang memiliki suami dan anak serta janda. Remaja menjadi sorotan yang paling menarik karena selain masih labilnya emosi mereka juga pengaruh orang tua dan lingkungan sangat berperan. Masyarakat menjadi resah dengan keadaan seperti ini, kecemasan orang tua dan tuntutan pada pihak sekolah semakin tinggi. Tidak dipungkiri pemerintah dan dinas sosial terkait sudah sering melakukan penertiban pada lokalisasi dan memberikan pemberdayaan kepada mereka melalui lembaga sosial. Isu seperti ini menjadi semakin rumit jika alasan ekonomi dan pemenuhan kebutuhan hidup seharihari. Terkait hal tersebut PSK telah mendapatkan pengarahan tentang bahaya seks bebas yaitu Penyakit Menular Seksual (PMS) sampai moral anak bangsa yang terkikis.

Biasanya tempat mereka beroperasi beragam mulai dari pusat perbelanjaan, pinggir-pinggir jalan bila malam hari dan bahkan melalui whatsaap atau pemesanan online. Gaya berpakaian sangat mudah dikenali, dengan pakaian yang seksi dan terbuka, Mereka cenderung beroperasi tengah malam dan memiliki kode-kode supaya tidak terjaring petugas keamanan dan PSK cenderung menyembunyikan identitas mereka sebagai PSK supaya tetap diterima masyarakat dan bersosialisasi dengan baik. Komunikasi antar PSK biasanya lebih banyak menggunakan bahasa non verbal, cara ini supaya memudahkan interaksi dan pergaulan dengan sesama PSK. Jika kita telaah komunikasi yaitu pesan yang disampaikan baik secara verbal maupun non verbal agar lawan bicara dapat memahami maksud pembicaraan. Ini menjadi menarik mengapa justru kode secara non verbal dan interaksi yang terjadi sesama PSK apakah dapat menimbulkan perselisihan atau justru kondisinya baik-baik saja. Berdasarkan wawancara kepada PSK dilokalisasi komunikasi yang terjadi biasanya non verbal dan biasanya mereka berinteraksi pada waktu malam hari saja. Untuk itu penulis sangat tertarik untuk menggali dan menelaah lebih lanjut bentuk komunikasi serta interaksi yang terjadi sesama PSK, mengetahui hubungan sosial dari PSK, mengetahui kehidupan sosial sesama PSK.

\section{TINJAUAN PUSTAKA}

\section{Pekerja Seks Komersial (PSK)}

PSK diartikan sebagai kurang beradab karena keroyalan relasi seksualnya dalam bentuk penyerahan diri pada banyak laki-laki untuk pemuasan seksual dan mendapatkan imbalan jasa atau uang bagi pelayanannya. PSK merupakan peristiwa penjualan diri (persundalan) dengan jalan memperjualbelikan badan, kehormatan, dan kepribadian kepada banyak orang untuk memuaskan nafsunafsu seks dengan imbalan pembayaran (Kartini Kartono, 2009). 
Pekerja Seks Komersial adalah perempuan yang pekerjaannya menjual diri kepada siapa saja atau banyak laki - laki yang membutuhkan pemuas nafsu seksual. Selain itu para PSK adalah perempuan yang melakukan 15 hubungan seksual dengan banyak laki - laki diluar pernikahan dan sang perempuan memperoleh imbalan uang dari laki - laki yang menyetubuhinya (Susanti Dian, 2006).

\section{Faktor Penyebab Timbulnya Psk}

Kartono (2013) menyebutkan beberapa peristiwa sosial penyebab timbulnya PSK antara lain:

a. Tidak adanya undang-undang yang melarang pelacuran. Juga tidak ada larangan terhadap orangorang yang melakukan relasi seks sebelum pernikahan atau di luar pernikahan.

b. Adanya keinginan dan dorongan manusia untuk menyalurkan kebutuhan seks, khususnya di luar ikatan perkawinan.

c. Komersialisasi dari seks, baik dipihak wanita maupun germogermo dan oknum-oknum tertentu yang memanfaatkan pelayanan seks. Jadi, seks dijadikan alat yang jamak guna (multipurpose) untuk tujuan-tujuan komersialisasi.

d. Dekadensi moral, merosotnya norma-norma susila dan keagamaan pada saat-saat orang mengenyam kesejahteraan hidup dan ada pemutarbalikan nilai-nilai pernikahan sejati.

e. Semakin besarnya penghinaan orang terhadap martabat kaum wanita dan harkat manusia. f. Kebudayaan eksploitasi pada zaman modern ini, khususnya mengeksploitasi kaum lemah/wanita untuk tujuan-tujuan komersil.

g. Ekonomi laissez-faire (istilah untuk pasar bebas) menyebabkan timbulnya sistem harga berdasarkan hukum "jual dan permintaan, yang diterapkan pula dalam relasi seks.

h. Peperangan dan masa-masa kacau (dikacaukan oleh gerombolangerombolan pemberontak) di dalam negeri meningkatkan jumlah pelacuran.

i. Adanya proyek-proyek pembangunan dan pembukaan daerah-daerah pertambangan dengan konsentrasi kaum pria, sehingga mengakibatkan adanya ketidakseimbangan rasio dan wanita di daerah-daerah tersebut.

j. Perkembangan kota-kota, daerahdaerah pelabuhan dan industri yang sangat cepat dan menyerap banyak tenaga buruh serta pegawai pria, juga peristiwa urbanisasi tanpa adanya jalan keluar untuk mendapatkan kesempatan kerja terkecuali menjadi wanita PSK bagi anakanak gadis.

k. Bertemunya macam-macam kebudayaan asing dan kebudayaakebudayaan setempat.

\section{Akibat Yang Ditimbulkan}

Dampak yang Ditimbulkan bila Seseorang Bekerja Sebagai PSK (Afrianti, 2014): 
1. Keluarga dan masyarakat tidak dapat lagi memandang nilainya sebagai seorang perempuan

2. Stabilitas sosial pada dirinya akan terhambat, karena masyarakat hanya akan selalu mencemooh dirinya.

3. Memberikan citra buruk bagi keluarga.

4. Mempermudah penyebaran penyakit menular seksual, seperti gonore, klamdia, herpes kelamin, sifilis, hepatitis B dan HIV/AIDS.

5. Instansi pemerintah yang terkait masih selalu menganggap PSK sebagai pihak yang paling bersalah.

\section{Stigma Masyarakat}

Stigma yang Menyebabkan PSK dianggap Sebagai Pekerjaan yang Tidak Bermoral (Afrianti, 2014):

1. Pekerjaan ini identik dengan perzinahan yang merupakan suatu kegiatan seks yang dianggap tidak bermoral oleh banyak agama.

2. Perilaku seksual oleh masyarakat dianggap sebagai kegiatan yang berkaitan dengan tugas reproduksi yang tidak seharusnya digunakan secara bebas demi untuk memperoleh uang.

3. Pelacuran dianggap sebagai ancaman terhadap kehidupan keluarga yang dibentuk melalui perkawinan dan melecehkan nilai sakral perkawinan.
4. Kaum wanita membenci pelacuran karena dianggap sebagai pencuri cinta dari laki-laki (suami) mereka sekaligus pencuri hartanya.

\section{INTERAKSI SOSIAL}

$\begin{array}{ccr}\text { Interaksi } & \text { sosial } & \text { adalah } \\ \text { hubungan-hubungan } & \text { sosial } & \text { yang }\end{array}$ dinamis yang berkaitan dengan orang perorangan, kelompok perkelompok, maupun perorangan terhadap perkelompok ataupun sebaliknya (Elly \& Usman, 2011). Interaksi sosial adalah hubungan timbal balik antara individu dengan individu, individu dengan kelompok, dan kelompok dengan kelompok(Soekanto,2010).

\section{Bentuk-bentuk Interaksi Sosial}

Bentuk-bentuk interaksi sosial yang berkaitan dengan proses asosiatif dapat terbagi atas bentuk kerja sama, akomodasi, dan asimilasi (Afrianti,2014)

a) Kerjasama merupakan suatu usaha bersama individu dengan individu atau kelompok-kelompok untuk mencapai satu atau beberapa tujuan.

b) Akomodasi dapat diartikan sebagai suatu keadaan, dimana terjadi suatu keseimbangan dalam interaksi antara individu - individu atau kelompok- kelompok manusia berkaitan dengan norma norma sosial dan nilai - nilai sosial yang berlaku dalam masyarakat. Usaha itu dilakukan untuk mencapai suatu kestabilan.

c) Asimilasi merupakan suatu proses dimana pihak-pihak yang berinteraksi mengindentifikasikan dirinya dengan kepentingan- 
kepentingan serta tujuantujuan kelompok.

\section{Bentuk interaksi yang berkaitan dengan proses disosiatif ini dapat terbagi atas bentuk persaingan, kontravensi, dan pertentangan (Afrianti, 2014).}

a) Persaingan merupakan suatu proses sosial, dimana individu atau kelompok- kelompok manusia yang bersaing, mencari keuntungan melalui bidang-bidang kehidupan.

b) Bentuk kontravensi merupakan bentuk interaksi sosial yang sifatnya berada antara persaingan dan pertentangan.

c) pertentangan merupakan suatu proses sosial dimana individu atau kelompok berusaha untuk memenuhi tujuannya dengan jalan menentang pihak lawan yang disertai dengan ancaman dan kekerasan.

\section{METODE PENELITIAN}

Metode yang peneliti gunakan pada studi kasus ini adalah pendekatan kualitatif dengan menggunakan alat tes berupa observasi dan wawancara. Dalam menganalisis data yang tersedia, peneliti menggunakan langkah-langkah sebagai berikut :

1. Reduksi Data, yaitu data yang diperoleh ditempat penelitian langsung dirinci secara sistematis setiap selesai mengumpulkan data, lalu laporan tersebut direduksikan yaitu dengan memilah hal-hal pokok yang sesuai dengan fokus penelitian.
2. Penyajian Data, yaitu penyajian kesimpulan informasi yang memberi kemungkinan adanya penarikan kesimpulan dan pengambilan tindakan.

3. Penarikan kesimpulan dan verifikasi dari data-data yang telah diperoleh.

\section{HASIL DAN PEMBAHASAN}

\section{A. DINAMIKA PSIKOLOGIS}

Subjek dalam penelitian memiliki jiwa sosial yang tinggi dalam kesehariannya, namun interaksi subjek dengan lingkungan kurang baik. Hal ini dikarenakan pekerjaan subjek yang menuai kontra di masyarakat terutama pada lingkungan tempat tinggal dan tempat kerjanya. Karena itu subjek merasa canggung untuk berinteraksi dengan lingkungannya. Tidak hanya di lingkungan sosial, bahkan antara sesama PSK terdapat persaingan dan komunikasi yang dilakukan dingin dan penuh basa-basi. Interaksi sosial subjek antara sesama PSK sangat tidak sehat, mereka saling menyindir. Hal tersebut tidak di respon dan cenderung diabaikan oleh subjek. Ini terjadi karena perasaan iri terhadap subjek dan keinginan untuk memusuhi subjek karena daya tarik subjek serta keramahannya pada pelanggan.

Berdasarkan proses belajar dan pengalaman dari frame of reference, subjek belajar untuk beradaptasi dengan lingkungan sekitar. Subjek juga belajar bagaimana cara menghadapi komentar-komentar dan sindiran 
yang sering ditujukan padanya. Subjek dapat memberikan penilaian dan membentuk skema terhadap sikap-sikap lingkungan dalam merespon tingkah lakunya. Bentuk interaksi subjek bersifat negative karena kontak sosial dan komunikasi terhadap lingkungannya terjadi penolakan. Hal ini sesuai dengan pendapat Afrianti (2014) dimana persaingan merupakan suatu proses sosial, dimana individu atau kelompokkelompok manusia yang bersaing, mencari keuntungan melalui bidang-bidang kehidupan.

\section{B. DIAGNOSIS}

Subjek mulai menjalani profesi sebagai PSK ketika berusia 14 tahun, pada saat itu subjek dituntut untuk menghasilkan uang demi membantu kondisi ekonomi keluarga. Hal ini menyebabkan subjek putus sekolah, Bila dilihat dari faktor internal. Subjek menikmati pekerjaannya dan merasa nyaman dengan kondisi keuangannya hasil sebagai seorang PSK. Sedangkan dari faktor eksternal, tuntutan ekonomi dan tidak ada masalah dari pihak keluarga maka subjek tidak mengalami masalah dengan keluarganya.

Dengan demikian interaksi sosial bagi subjek tidak lagi menjadi hal yang penting, karena subjek merasa bahwa ia melakukan itu bukan untuk mencari teman atau pengakuan dari lingkungan sekitar, tetapi memang tuntutan kondisi ekonomi yang tidak memungkinkan bertahan hidup. Hal ini sesuai dengan pendapat Kartono (2013) Perkembangan kota-kota, daerahdaerah pelabuhan dan industri yang sangat cepat dan menyerap banyak tenaga buruh serta pegawai pria, juga peristiwa urbanisasi tanpa adanya jalan keluar untuk mendapatkan kesempatan kerja terkecuali menjadi wanita PSK bagi anakanak gadis.

\section{PROGNOSIS}

Berdasarkan data dari subjek maka subjek ke depannya akan tetap menjalani profesinya sebagai PSK karena subjek merasa bahwa inilah pekerjaan yang tepat untuknya dengan pendidikan yang sangat minim. Meskipun ada kesempatan dan penawaran dari pihak keluarga ia sudah yakin dengan keputusannya untuk terus berprofesi sebagai PSK. Alasan utama tetap bekerja sebagai PSK ia harus membiayai kedua adiknya yang masih duduk di bangku Sekolah Dasar (SD). Subjek merasa cukup puas dengan uang yang didapatkannya, ia merasa kondisi perekonomian keluarganya akan baik saat ini dan masa depan dengan keputusannya tersebut.

Dengan demikian walaupun terdapat perselisihan dan persaingan pada subjek di tempatnyan bekerja, ia tetap merasa bahwa itu bukan suatu masalah karena ia merasa bahwa setiap lingkungan pasti ada kondisi persaingan. Selama ini ia masih bias mengatasinya dan merasa tidak stress. 


\section{SIMPULAN DAN SARAN}

Interaksi sosial subjek antara sesama PSK tidak baik, hal ini karena persaingan dan kontak sosial serta komunikasi yang terjadi tidak sehat. Subjek tidak menjadikan itu masalah dan tetap menjalani profesinya sebagai PSK karena tuntutan ekonomi keluarga dimana ia menghidupi keluarga dan membiayai adiknya bersekolah. Dalam frame of reference subjek ia merasa bahwa stigma masyarakat akan pekerjaannya bukan menjadi soal, karena yang ia perlukan bukan pengakuan di lingkungan sosial.

Saran kepada subjek untuk lebih mencari tahu tentang kesehatan reproduksi bila melakukan hubungan seks berganti pasangan dan secara moral di lingkungan masyarkat profesi sebagai PSK merupakan suatu pekerjaan yang tidak sesuai dengan adat istiadat ketimuran. Kepada masyarakat, untuk memberikan perhatian dan membina para PSK agar memberikan motivasi supaya hidupnya lebih baik kedepannya dengan cara yang terhormat dan sesuai demgan moral bangsa Indonesia.

\section{DAFTAR PUSTAKA}

Afrianti, Rahma.2014. Interaksi Sosial Psk (Pekerja Seks Komersial) Di Kota Makassar (Studi Kasus Di Jalan Nusantara). Makasar: UIN Alauddin Makassar.

Elly M Setiadi \& Usman Kolip,2011.

Pengantar Sosiologi.

Pemahaman Fakta dan

Gejala Permasalahan

Sosial: Teori, Aplikasi, dan
Pemecahannya. Jakarta: Kencana

Soerjono Soekanto,2010. Sosiologi Suatu Pengantar. Jakarta: Rajawali Press.

Kartono, Kartini. 2009. Patologi Sosial. Jilid 1. Jakarta : Rajawali Pers.

Kartono, Kartini. 2013. Patologi Sosial. Jakarta. Rajawali Pers

Susanti, Dian, 2006, Profil Pekerja Seks Komerisal Kelas Bawah Dalam Mengelola masa Depan, Semarang: Skripsi. 